PUC Minas

PONTIFÍCIA UNIVERSIDADE CATÓLICA DE MINAS GERAIS - IEC PÓS-GRADUAÇÃO EM HISTÓRIA DA ARTE (MA)

MATHEUS MAURICIO CIRINO GONÇALVES

\title{
MICHELANGELO BUONARROTI: \\ $O$ artista dos papas e o relacionamento com a Igreja de Roma entre 1496 a 1564.
}




\section{MICHELANGELO BUONARROTI:}

$O$ artista dos Papas e o relacionamento com a Igreja de Roma entre 1496 a 1564.

Trabalho de Graduação apresentado

à Pontifícia Universidade Católica, como requisito final para obtenção

do Título de Especialista em

História da Arte, sob orientação da Prof a . Vânia Myrrha de Paula e Silva.

Belo Horizonte - Outubro de 2019 


\section{AGRADECIMENTOS}

Ao onipotente arquiteto, designer e artista do universo, Deus.

À querida e atenciosa orientadora Vânia, que me inspirou realizar esta pesquisa através de seu amor pela arte. 


\title{
MICHELANGELO BUONARROTI: \\ $O$ artista dos Papas e o relacionamento com a Igreja de Roma entre 1496 a 1564.
}

\author{
Matheus Mauricio Cirino Gonçalves ${ }^{1}$
}

\section{RESUMO/ABSTRACT}

Michelangelo Buonarroti, ao longo de seus oitenta e oito anos, serviu a nove papas, e o presente trabalho foca nestas relações entre o artista e os pontífices.

Michelangelo foi o artista responsável pela escultura da Pietá, pela pintura do teto da Capela Sistina, pela pintura do Juízo Final, dos túmulos de pessoas importantes da Igreja e de projetos arquitetônicos como a fachada e a cúpula da Basílica de São Pedro.

Todas estas obras foram envoltas em relacionamentos conturbados, intrigas artísticas e muito sofrimento por parte do artista, desta forma, estas questões tornaramse elementos-chave para a elaboração deste trabalho.

Michelangelo Buonarroti, during his eighty-eight years, served nine popes, and the present work focuses on these relations between the artist and the pontiffs.

Michelangelo was the artist responsible for the sculpture of Pietá, the painting of the ceiling of the Sistine Chapel, the painting of The Last Judgment, the tombs of important people of the Church and architectural projects such as the facade and the dome of St. Peter's Basilica.

All these works were surrounded by troubled relationships, artistic intrigues and much suffering on the part of the artist, so these questions became key elements for the elaboration of this work.

Palavras-chave: Michelangelo; Papas; Renascimento Italiano.

Keywords: Michelangelo; Popes; Italian Renaissance.

\footnotetext{
${ }^{1}$ Especializando em História da Arte (PUC-MG), Graduado em Design Gráfico (INAP).
} 


\section{LISTA DE FIGURAS}

Figura 1 - Papas que Michelangelo Serviu Entre 1496 até 1564 e Linha do Tempo das

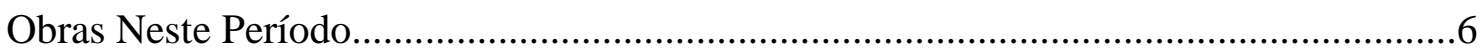




\section{SUMÁRIO}

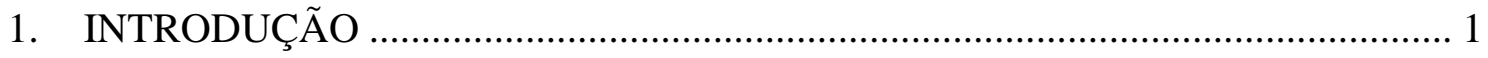

2. ROMA UMA CIDADE EM RECONSTRUÇÃO .............................................. 7

2.1 A Pietá, Um Recomeço Para Michelangelo............................................... 8

2.2 Júlio II, o Papa Terrível......................................................................... 9

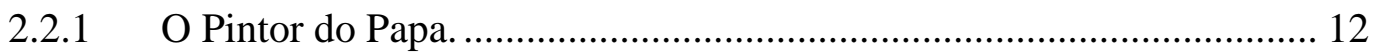

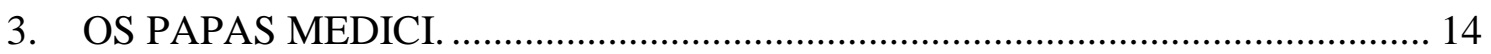

3.1 Leão X, O Papa Mundano....................................................................... 14

3.2 Adriano VI, Um Ponto na História. ............................................................. 18

3.3 Clemente VII, Decisões Precipitadas......................................................... 19

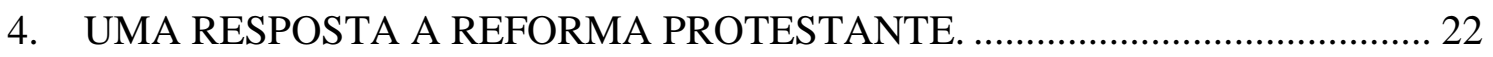

4.1 Paulo III, O Papa da Contra-Reforma..................................................... 22

4.2 Michelangelo, o Arquiteto Chefe Da São Pedro........................................ 26

5. ÚLTIMOS ANOS DE MICHELANGELO, ARQUITETO SUPREMO. ............... 28

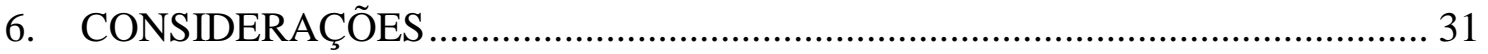

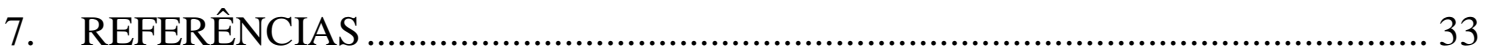




\section{INTRODUÇÃO}

O presente trabalho se trata de uma análise biográfica competente às relações do artista Michelangelo Buonarroti com os papas a quem serviu em sua vida épica, e os frutos de trabalho gerados. Faz-se a obrigação de esclarecer que vários acontecimentos e personagens importantes na vida de Michelangelo ao longo de seus oitenta e oito anos vividos não puderam ser contemplados mediante a proposta e a formatação deste.

As datas que seguem a apresentação dos personagens históricos são: o ano de nascimento e morte, e no caso dos papas relatados ao longo do trabalho, as datas são referentes ao início e final do pontificado.

Michelangelo teve duas biografias escritas ainda em vida, e as duas tornam-se a primeira referência para a escrita deste trabalho.

Michelangelo Buonarroti Di Ludovico Simoni, assim escrito por Giorgio Vasari ${ }^{2}$ (1511-1574), nasceu em 6 de março de 1475, aos arredores de Florença, em Caprese, atualmente parte da região de Arezzo, Itália.

Filho de Ludovico Simon Buonarroti (1444-1534) e de Francesca di Neri del Miniato del Sera ${ }^{3}$, de acordo com Vasari (2011, p.714), recebeu este nome, Michele Agnolo que significa Anjo Miguel, um ser celestial e divino, mais que um mero mortal.

Michelangelo nasceu em uma família de status ${ }^{4}$, entretanto com poucos recursos. Seu pai era podestá da cidade de Caprese, ou seja, uma espécie de autoridade do pequeno vilarejo, título este que não garantia recursos suficientes para desfrutar com luxos a vida junto à família de muitos filhos, cinco ao todo.

Desde criança, Michelangelo já fazia desenhos nas paredes e em pedaços de papel, algo que chamou a atenção de seu pai.

\footnotetext{
${ }^{2}$ Giorgio Vasari, é conhecido como o primeiro historiador da arte, escreveu Le vite de' più eccellenti pittori, scultori e architettori (A vida dos mais excelentes pintores, escultores e arquitetos). Foi amigo e contemporâneo de Michelangelo.

3 Pouco se sabe sobre a mãe de Michelangelo, de acordo com GAYFORD (2015, P.40), ela provavelmente teria entre os seus 18 anos quando deu à luz a Michelangelo. Sabe-se que ela veio de uma tradicional família florentina, os Rucellai.

${ }^{4}$ Os Buonarroti faziam parte da classe média florentina, mas diversas ocasiões como perca de dotes por excesso de filhos homens e outras adversidades culminaram no enfraquecimento financeiro dentre as gerações seguintes até chegar a Ludovico Simoni.
} 
Vasari relata que Ludovico ao perceber o talento do filho para as artes ${ }^{5}$, foi até o ateliê de um conhecido artista florentino, Domenico Ghirlandaio ${ }^{6}$ (1449-1494) e insistiu para que o mestre empregasse o filho em seu ateliê mediante ao talento precoce do Jovem. Ascânio Condivi ${ }^{7}$ (1525-1574) relata que na verdade, foi Francesco Granacci (1469-1543), seu amigo de infância e um dos aprendizes de Ghirlandaio que incentivou Michelangelo como artista e o levou ao ateliê do mestre algumas vezes. Fato é que após alguma negociação entre o pai de Michelangelo e Ghirlandaio, houve um acordo para um contrato de três anos e de um salário para o jovem.

Durante o período em que Michelangelo foi aluno no ateliê do Ghirlandaio, o mestre viu um talento acima de todos os demais alunos e em algumas circunstâncias, até mesmo acima dele próprio, como relata Vasari:

"Quando Domenico trabalhava na capela-mor de Santa Maria Novella, certo dia em que estava ausente, Michele Agnolo se pôs a retratar o andaime com algumas mesas, todo o material da arte e a alguns jovens que ali trabalhavam. Domenico, ao voltar e ver o desenho de Michele Agnolo, disse: "Ele sabe mais que eu"; e ficou muito admirado com a nova maneira e a nova forma de imitação que, graças ao tino recebido do céu, eram praticadas por um jovem em idade tão tenra, coisas que na verdade, eram as mais desejáveis possíveis na prática de um artista que já trabalhasse havia muitos anos". VASARI (2011, p. 714).

Em 1480, um membro da famosa família Medici, Lourenço (1449-1492) mais conhecido como o Magnífico ${ }^{8}$ adquiriu um imenso jardim na Praça da Igreja de San Marco, em Florença.

\footnotetext{
${ }^{5}$ É sabido através de Condivi, que por tradição, o pai e os tios de Michelangelo não queriam de imediato que o jovem fosse um artista, por que até então, não era uma profissão digna de famílias mais tradicionais, como por exemplo, era a profissão de tabelião. No fim das contas, Michelangelo ganhara mais dinheiro que qualquer outro membro da família Buonarroti.

${ }^{6}$ Ghirlandaio, que já era um conhecido artista naqueles tempos, aparece também como o primeiro mestre de Michelangelo, embora na biografia escrita pro Ascânio Condivi em 1553, Michelangelo relate por questões de ego que pouco aprendeu de fato com o mestre.

${ }^{7}$ Condivi foi amigo e aprendiz de Michelangelo, em sua biografia, existe muito ou totalmente da visão do próprio artista sobre os fatos que cercaram sua existência. Alguns dizem que a biografia escrita por Condivi é uma autobiografia de Michelangelo apenas com a assinatura de Condivi.

8 Lourenço foi patrono das artes e de extrema importância para o Renascimento italiano, pois se interessava nas antigas culturas grega e romana, atraindo artistas multidisciplinares e trazendo de volta manuscritos perdidos ou ignorados durante a idade média, algo que cominou em grandes evoluções cientificas, médicas e artísticas.
} 
Neste jardim, ao passar dos anos, começaram a se reunir os maiores artistas e intelectuais da época. Lourenço ficou empolgado com tudo isto, entretanto, apesar de Florença possuir excelentes e renomados pintores, ele sentiu que naqueles tempos, carecia de nobres escultores que honrassem o nome da cidade. Segundo Vasari (2011, p.715) ${ }^{9}$, Lourenço solicitou a Ghirlandaio, jovens de seu ateliê para trabalhar sobre seu mecenato ${ }^{10}$ no jardim e que pudessem suprir essa carência. Ghirlandaio indicou dois jovens, um era Michelangelo e o outro, Francesco Granacci.

No Jardim, Michelangelo teve contato com outro jovem artista, Pietro Torrigiano ${ }^{11}$ (1472-1528), e vendo suas esculturas em argila, começou a copiá-las com exatidão, provavelmente com vontade de superá-las.

Michelangelo logo começou a se aventurar em esculturas de mármore, sobre incentivo de Lourenço que maravilhado com o talento do jovem, decidira o apadrinhar, cria-lo como um de seus filhos dentro de sua casa e lhe pagar um salário de cinco ducados, uma quantia relevante para a época.

É importante ressaltar que as esculturas em mármore foram suas principais características pelo resto da vida, o próprio Michelangelo assinava como escultor. De acordo com Berriel (2008, pp.41-42, apud Condivi), Michelangelo costumava dizer que o motivo de trabalhar tão bem com as ferramentas no mármore é que quando pequeno, foi entregue a uma ama de leite em Settignano, cidade próxima a Florença que vinha de uma família de pedreiros, e desta forma através do leite, herdou tais características.

Michelangelo permaneceu na casa dos Medici por cerca de dois anos, até a morte de Lourenço em 1492. Durante este tempo, ele esculpiu um velho Fauno, que se perdeu, uma Madonna da Escada e fez também uma Batalha dos Centauros ${ }^{12}$. Além destas obras, é de importância categórica ressaltar que Michelangelo conviveu com grandes

\footnotetext{
${ }^{9}$ Condivi conta que Granacci foi quem levou Michelangelo até o Jardim de Lourenço, e não a pedido de Lourenço como afirma Vasari.

10 O Mecenas é o patrocinador dos artistas, que incentiva o trabalho e recompensa o artista financeiramente por ele. Nos tempos de Michelangelo, era de extrema importância que um artista tivesse um bom mecenas, ou seja, com recursos suficientes para patrocinar grandes feitos e elevar ainda mais a fama de um grande artista.

11 Torrigiano ficou muito conhecido por um episódio em que movido por inveja e provavelmente ironizado por Michelangelo, o quebra o nariz com um soco. (GAYFORD 2011, p.88).

12 A Madona da Escada e a Batalha dos Centauros atualmente se encontram na casa Buonarroti em Florença.
} 
intelectuais da época, como Angelo Poliziano ${ }^{13}$ (1454-1494), que foi um exímio frequentador da casa dos Medici e professor de Michelangelo.

Poliziano com seus estudos filosóficos retomados da Grécia e Roma antigas foi um dos ideais que inspiraram obras de Michelangelo, como a Batalha dos Centauros.

Sabe-se de acordo com Berriel (2008, p.49, apud Condivi), que após o período na casa dos Medici, Michelangelo começou a estudar anatomia em defuntos na igreja e hospital de Santo Espírito a fim de alcançar a perfeição na arte.

Esta prática não era bem vista pela Igreja e muito menos pelos familiares dos corpos dissecados por Michelangelo, mas se tornou de extrema importância para as obras futuras do artista que com ótima memória, observou cada veia, tendão e músculos presentes no corpo humano. Graças a esta boa memória, é que Michelangelo também não se esqueceu das antigas esculturas que sempre via na casa dos Medici.

De acordo com Zöllner e Thoenes (2017 p.42), Michelangelo esculpiu um Cupido Adormecido $^{14}$, provavelmente por vontade própria, baseando-se em uma antiga escultura que era de posse dos Medici. Esta escultura é o começo das futuras e turbulentas relações entre Michelangelo e a Igreja, ainda que este não soubesse.

“Aparentemente por intermédio de Lorenzo de Pierfrancesco de' Medici ${ }^{15}$, a escultura chegou a Roma, onde foi comprada pelo comerciante de arte Baldassare del Milanese, por 30 ducados. Este fêla passar por antiguidade ${ }^{16}$ e conseguiu vendê-la pelo inflacionado preço de 200 ducados ao cardeal Raffaele Riario, um poderoso membro do clero e um importante colecionador de arte em Roma”. ZÖLLNER e THOENES (2017, pp.42-45).

A venda do Cupido Adormecido, como já dito, ocorreu por 200 ducados ao cardeal Rafaelle Riario ${ }^{17}$ (1461-1521), que logo recebeu a informação de que esta escultura não

\footnotetext{
${ }^{13}$ O Florentino Angelo Poliziano foi um poeta, erudito e um dos grandes responsáveis por reviver o latim na renascença e reforçar o humanismo que foi símbolo do Renascimento italiano.

${ }^{14}$ Este cúpido hoje está desaparecido.

15 Lorenzo di Pierfrancesco de Medici (1463-1503), era o filho mais velho de Lourenço de Medici e assumiu o lugar do pai na família quando este faleceu em 1492.

${ }^{16}$ Condivi relata que foi Lorenzo di Pierfrancesco quem sugeriu a Michelangelo fazer a escultura do Cupido Adormecido parecer antiga, para valer mais.

17 Rafaelle Riario era sobrinho do Papa Sisto IV (1471-1484), e primo de Giulliano Della Rovere, o imponente futuro Papa Júlio II.
} 
se tratava de uma verdadeira antiguidade, mas que na realidade tinha sido feita em Florença.

Indignado por ter sido enganado, o cardeal Riario enviou Jacopo Galli (1460-1505), a pessoa responsável por seus negócios, até Florença para descobrir quem fez a falsificação. Ao descobrir que esse artista era um jovem, ao invés de punir Michelangelo pela falsificação, Galli o contou sobre o verdadeiro valor de venda e prometeu ao artista que se se este fosse até o encontro do cardeal em Roma, lá receberia o restante da quantia que foi omitida por Baldasare.

Com algum receio sobre esta visita, entretanto enfurecido com o valor de apenas 30 ducados que recebeu pela venda, Michelangelo aceitou o convite de Galli e ambos seguiram para a primeira visita de Michelangelo a Roma, sendo este o ponto de partida para a análise do presente trabalho.

A figura 1 ilustra respectivamente os papas com que Michelangelo trabalhou diretamente durante todo o período em que viveu entre Roma e Florença, e a lista de obras que realizou sob a tutela dos pontífices.

Para a linha do tempo presente na figura, foram consideradas as obras realizadas em favor dos papas ou da alta cúpula da Igreja, partindo do Cupido Adormecido feito para o cardeal Riario, até a morte de Michelangelo. A exceção é o $D a v i^{18}$, que foi feito para a cidade de Florença, mas se torna relevante para a fama posterior do artista.

É importante frisar, que durante este grande período, Michelangelo realizou muitas outras obras de pintura, escultura e arquitetura que porventura não serão abordadas neste trabalho.

\footnotetext{
${ }^{18}$ Michelangelo construiu o Davi em um bloco de mármore já anteriormente tentando por outros artistas em Florença, atualmente a escultura se encontra na Academia de Belas Artes de Florença.
} 


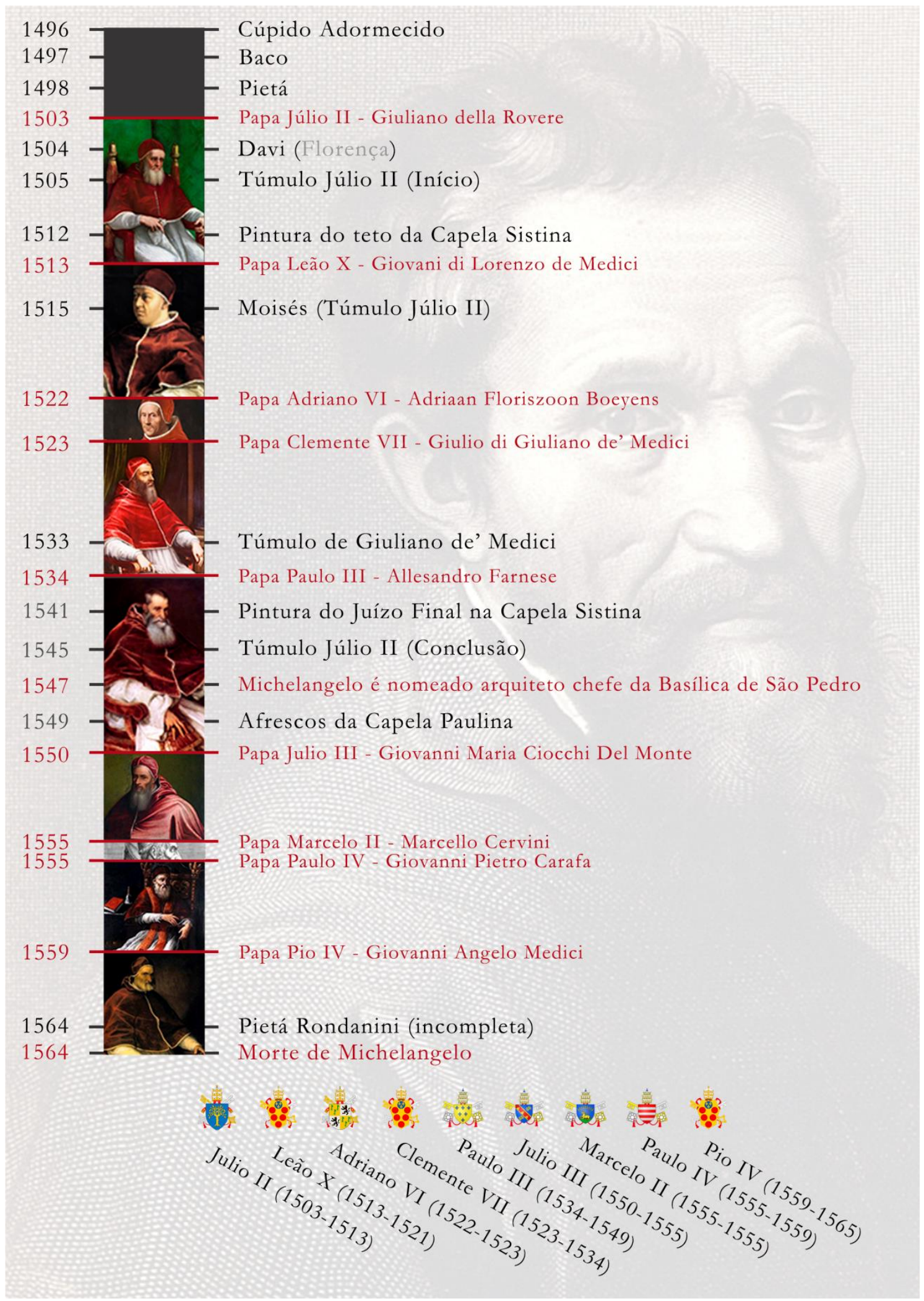

1 - Papas que Michelangelo serviu entre 1496 até 1564 e linha do tempo das obras neste período. Fonte: (Elaborado pelo autor). 


\title{
2. ROMA UMA CIDADE EM RECONSTRUÇÃO.
}

O que segue, é um trecho da primeira carta de que se tem registro da vasta correspondência que Michelangelo faria por toda a vida. Esta carta marca a chegada do artista em Roma após o convite de Jacopo Galli para o artista ir conhecer o cardeal Riario.

\begin{abstract}
"Magnífico Lorenzo etc.,
Esta é somente para avisar-vos que chegamos, são e salvos, no passado sábado. Em seguida fomos visitar o Cardeal de San Giorgio, e entreguei-lhe a vossa carta. Pareceu alegrar-se ao me ver, e imediatamente pediu-me que fosse ver certas estátuas; isto me ocupou o dia inteiro, de maneira que não pude entregar vossas outras cartas neste dia. No domingo, tendo ido a sua nova casa, o Cardeal mandou chamar-me. Fui vê-lo, e me perguntou o que me pareciam as coisas que havia visto. Disse-lhe o que pensava - e, certamente, parece-me que possui muitas coisas belas. $\mathrm{O}$ Cardeal perguntou-me então se eu me atreveria a realizar uma bela obra. Respondi que não faria nada tão grande, mas que ele veria o que eu iria fazer. Compramos um bloco de mármore para uma figura de tamanho natural, e comecei a trabalhar na segunda-feira ${ }^{19}$. BUONARROTI $(2009$, p.28).
\end{abstract}

Quando chegou a Roma, Michelangelo se deparou de acordo com Gayford (2015, p.139) com uma cidade que mais parecia uma colônia vivendo entre os destroços da antiga e potente Roma dos tempos de Império. O que ocorre é que Roma foi invadida e saqueada por diversas vezes ${ }^{20}$, se enfraquecendo politicamente de tal forma que o papado chegou a se transferir para a cidade francesa de Avinhão ${ }^{21}$. Durante este tempo, a cidade ficou abandonada e em ruinas.

19 Esta obra a quem Michelangelo se refere se trata de um Baco, o deus romano do vinho que Michelangelo fez para o cardeal Riario. O cardeal considerou a obra de mau gosto e esta acabou sendo adquirida por Jacopo Galli, que não queria ver o amigo Michelangelo desanimar pelo ocorrido.

${ }^{20}$ Desde a decadência e por consequência a queda do Império romano, a cidade de Roma sofreu diversos ataques de outros povos, como por exemplo, os bárbaros. Desta forma a cidade se tornou cada vez menos populosa e em regresso cultural.

${ }^{21}$ Entre 1309 a 1377 a sede da Igreja se transferiu de Roma para Avinhão, mostrando o enfraquecimento de Roma neste período enquanto a França de Filipe IV (1285-1314) crescia como potência. 


\subsection{A Pietá, Um Recomeço Para Michelangelo.}

Em Roma, Michelangelo recebeu mais apoio de Jacopo Galli do que de Riario que recusou a encomenda do Baco citada na carta por Michelangelo, e por consequência desanimou o jovem artista que almejava coisas grandes. Galli foi um bom amigo e protetor, tanto que logo após a recusa do Baco por Riario, ele afirmou toda a sua confiança em seu protegido.

No fim do outono de 1497 Galli conseguiu para Michelangelo uma encomenda do mais importante clérigo francês em Roma, o cardeal Jean de Bilhères-Lagraulas (1434-1499). De acordo com Gayford (2015, p.151), Numa carta escrita em 18 de novembro de 1497, o cardeal relata que Michelangelo faria uma Nossa Senhora da Piedade, ou em italiano, Pietá, que seria instalada numa capela localizada na antiga Basílica de São Pedro, dedicada ao rei da França.

Esta encomenda, afirmaria de uma vez por todas a genialidade de Michelangelo que logo foi à cidade de Carrara, conhecida por suas montanhas de um tipo especial de mármore, e tratou de escolher um bloco sem nenhum defeito para começar a trabalhar na escultura.

Ao concluir a obra, Michelangelo alcançou a perfeição nos detalhes do corpo do Cristo nu no colo da mãe. A obra chamou muito a atenção por causa do realismo obtido pelo artista, mas Michelangelo foi criticado pelo contraste entre o Cristo, em idade adulta e Maria que mais parece uma jovem.

O próprio Michelangelo é quem explica, de acordo com Berriel ( 2008, p 55, apud Condivi) que as mulheres castas se mantêm muito mais jovens que as não castas. E que isto também comprova a obra divina na mãe que não era necessária por parte do filho que já é o próprio Deus.

Vasari (2011, p.717) relata que de tanta dedicação e amor por esta escultura, Michelangelo gravou seu nome no cinto que fica por cima das vestes de Nossa Senhora $^{22}$. A Pietá torna-se muito relevante, pois ela foi o cartão de visitas de Michelangelo aos cidadãos romanos e principalmente a um cardeal e futuro papa que seria um de seus mais importantes protetores em toda sua vida.

\footnotetext{
22 Em sua reedição da vida de Michelangelo, Vasari explica que Michelangelo gravou seu nome na Pietá para afirmar sua autenticidade, pois os cidadãos acreditavam ser obra de outro artista.
} 


\subsection{Júlio II, o Papa Terrível.}

Se Roma estava em decadência e em ruínas, a Igreja era um reflexo de tudo isto. O poder exercido pelo príncipe da Igreja era algo desejado por muitos homens que sonhavam com o lugar mais alto da cúpula cristã, mas nem sempre, quem alcançava o cargo cumpria o verdadeiro papel perante o povo.

Um exemplo disto passa pelo papa que provavelmente é considerado o mais infame da história. Alexandre VI (1492-1503), nascido Rodrigo de Borja ou Borgia, como ficou conhecido na Itália, é o caso de como o poder sem escrúpulos pode ser destruidor.

Seu pontificado foi marcado por nepotismo, ganância e sexualidade desenfreada. McBrien (2009, P.274).

Homens como Rodrigo Borgia, contribuíram para a decadência de Roma, movidos por interesses pessoais e familiares e não em prol do povo ou da cidade.

A resposta contra a decadência de Roma vem após a morte de Alexandre VI, com um homem de forte personalidade e a energia de um imperador romano.

Este se nomeou ao ascender ao pontificado como Júlio II (1503-1513), ou seja, o sucessor do próprio Júlio II César.

Nascido Giuliano della Rovere, foi eleito papa após a rápida e questionável ${ }^{23}$ morte do sucessor de Alexandre VI, Pio III (1503-1503).

Della Rovere, assim como outros papas da história, foi sobrinho ${ }^{24} \mathrm{de}$ um papa anterior e eleito pela prática de simonia ${ }^{25}$. Seu tio, Sisto IV(1471-1484) nomeou seis sobrinhos para o Colégio de Cardeais, dentre eles della Rovere e Rafaelle Riario. Sisto também foi, de acordo com McBrien (2009, p.271), o responsável pela construção da Capela Sistina, do museu, e dos arquivos do Vaticano.

Scotti (2006, p.50) relata que Giulliano della Rovere, após um período em exílio (por conta de Alexandre VI, seu inimigo), retorna a Roma para a eleição papal de 1503, e ao entrar na antiga Basílica de São Pedro se deparou com a Pietá esculpida por

\footnotetext{
${ }^{23}$ A suspeita é de envenenamento, embora não exista comprovação.

24 O nepotismo, que varia da palavra nepote que em italiano significa "sobrinho", foi um grande problema na Igreja da Renascença, tanto que foi finalmente proibido no concílio de Trento em 1563.

${ }^{25}$ Compra de votos para um cargo eclesial.
} 
Michelangelo e ficou maravilhado. Desta forma, saiu da Basílica decidido a contar em breve com os serviços do responsável por tamanha proeza.

Gayford (2015, p.214) relata que o motivo que levou Júlio II a contratar os serviços de Michelangelo foram as recomendações do arquiteto florentino e amigo de Michelangelo, Giuliano da Sangallo (1443-1516), este era um dos protegidos do papa patrono das artes. Sangallo falou sobre a beleza triunfal de um Davi de mármore que Michelangelo tinha acabado de construir em Florença, além da própria Pietá que o pontífice conhecia de perto.

Em 1505, Júlio II chamou oficialmente Michelangelo a Roma, para o início de um trabalho. Tratava-se de um túmulo em homenagem ao próprio papa. O pontífice queria ter o maior túmulo já feito para um papa na história, e para Michelangelo, era uma oportunidade de se consagrar como o maior artista de todos os tempos, uma vez que o seu novo protetor tinha a vontade e os recursos necessários para tal feito.

De acordo com o projeto elaborado por Michelangelo, o túmulo deveria ser erigido dentro da antiga Basílica de São Pedro, e contaria com cerca de quarenta estátuas enfileiradas, incluindo profetas e escravos que representariam as artes liberais ${ }^{26}$. O papa aprovou o projeto, e desta forma, Michelangelo se dirigiu para as montanhas de Carrara a fim de encomendar as pedras necessárias para o projeto.

Berriel (2008, p.60, apud Condivi), relata que Michelangelo causou desconforto em outro artista do papa, o arquiteto Donato Bramante (1444-1514), que motivado por inveja e medo, por que Michelangelo constantemente encontrava erros em seus projetos, convenceu ao papa a não prosseguir com o túmulo naquele momento. De acordo com Gayford (2015, p.218), como Michelangelo passou cerca de oito meses em Carrara, o papa foi seduzido pelo projeto de Bramante que consistia em demolir a antiga Basílica de São Pedro e reerguer uma basílica muito mais esplendorosa, que mostrasse todo o poder da Igreja e do próprio pontífice que tivesse a coragem de levar este projeto a frente.

Júlio II iria adaptar uma parte da Basílica de São Pedro para erigir o túmulo em sua homenagem, mas provavelmente, por questões de consciência, resolveu adiar o projeto

\footnotetext{
${ }^{26}$ Pintura, escultura e arquitetura.
} 
do túmulo para se concentrar na própria Basílica. Em 1505, a antiga São Pedro já estava com cerca de mil e duzentos anos ${ }^{27}$ e corria risco de desabamento. Observando estas questões, Júlio II não hesitou onde papas anteriores hesitaram e decidiu que iria reconstruir a Basílica de São Pedro.

De acordo com Berriel (2008, p.62, apud CONDIVI), o projeto de Michelangelo foi o que motivou o papa a querer uma nova igreja, que comportasse melhor o túmulo em sua homenagem.

Quando Michelangelo retornou das pedreiras após meses fora de Roma, ele se deparou com as grandes obras que já estavam sendo feitas na antiga Basílica que aos poucos ia sendo destruída e dava lugar ao novo projeto de Bramante, seu rival.

Neste ponto, segundo Gayford (2015, p. 221 apud CONDIVI) o papa ia com frequência a uma casa em que Michelangelo estava em Roma, localizada na Marcel de Corvi, e como dois irmãos, discutiam sobre valores e andamento das obras. Entretanto, esta relação de "irmãos" mudaria ao longo do tempo em que Júlio II deixaria o projeto do túmulo com cada vez menos importância mediante ao projeto da Basílica e de retomada dos Estados Pontifícios ${ }^{28}$.

O primeiro ponto de colisão entre o artista e o patrono, ocorreu quando Michelangelo foi ao encontro de Júlio II para solicitar o dinheiro referente ao pagamento dos transportes e descarregamentos dos mármores para o túmulo e recebeu uma porta fechada, sem retorno do papa.

De acordo com Berriel (2008, p.63, apud CONDIVI), Michelangelo resolveu pagar o transporte por sua conta pensando em receber posteriormente do papa a quantia gasta, mas toda vez que ia solicitar dinheiro ao papa não era recebido pelo motivo de Júlio II estar sempre ocupado. Em uma destas, um criado do papa disse ao artista que recebeu ordens para não deixa-lo entrar. Um bispo que presenciou a cena logo questionou o criado se ele sabia com quem estava falando, o criado respondeu que pelo contrário, sabia exatamente com quem estava falando, mas estava seguindo ordens.

\footnotetext{
${ }^{27}$ Construída em cima do terreno onde antes era o circo do Imperador Nero, a primeira Basílica de São Pedro foi concluída e consagrada no ano 360. Acredita-se que ela foi construída exatamente no local onde o apóstolo e primeiro papa da Igreja, Pedro, foi crucificado de cabeça para baixo.

${ }^{28}$ Os Estados Pontifícios eram as regiões da Itália central doadas para Igreja ao longo da Idade Média, mas que aos poucos foram sendo tomadas com o enfraquecimento da Igreja em Roma.
} 
Michelangelo se sentiu expulso e humilhando e sua resposta ao criado foi que avisasse ao papa que se este quisesse vê-lo, que fosse ele mesmo atrás do artista em outro lugar fora de Roma.

De acordo com Gayford (2015, p.222), no dia do lançamento da pedra fundamental da nova Basílica, Michelangelo montou um cavalo e saiu em fuga para Florença. Júlio II ao descobrir, mandou seus homens irem atrás de Michelangelo que ao o encontrarem, lhe entregaram uma carta escrita pelo próprio papa onde estava escrito que o artista deveria voltar, sob pena de cair em desgraça.

Neste ponto, pode-se observar as fortes personalidades de Michelangelo e Júlio II. O papa, conhecido por ser um guerreiro terrível em suas invasões, estava tendo sua autoridade desafiada por um artista que já se considerava acima de um mero trabalhador, e que desta forma deveria ser tratado com a honra de cavalheiro. Observase também a intimidade do relacionamento entre os dois, uma vez que Michelangelo se portava diante do príncipe da Igreja como se portava na frente de um amigo comum, ou de um irmão. Michelangelo resolve fugir exatamente por perceber que estava sendo tratado apenas como mais um subalterno do papa.

Posteriormente, amigos florentinos de Michelangelo, provavelmente por medo de terem a cidade devastada por Júlio II, insistiram de forma amigável para que o artista regressasse a Roma e continuasse a trabalhar com o papa. Enviaram uma carta ao papa pedindo que aceitasse novamente o artista, e que no mundo não existe mais nenhum de igual talento, merecendo este ser tratado com respeito.

\subsubsection{O Pintor do Papa.}

Outra questão estava incomodando Michelangelo e porventura adiando seu retorno a Roma, esta questão se tratava de uma incumbência que Júlio II o deu. O tio do papa, Sisto IV, como já dito anteriormente, construiu uma capela, que por causa de seu nome, ficou conhecida como capela Sistina.

A capela da família della Rovere enfrentava problemas estruturais e com isto o teto apresentou rachaduras em alguns locais, as paredes laterais se curvaram e este se tornou um problema urgente, pois esta era a principal capela do Vaticano, onde o papa 
ia fazer suas orações. Júlio II queria que Michelangelo fosse o responsável por este grande empreendimento.

Bramante de acordo com Gayford (2015, p.224) dizia para Júlio II que o motivo de Michelangelo recusar a encomenda era o medo, pois ele nunca havia feito nada nesta proporção e que pintar um teto era diferente de pintar um mural, pois a perspectiva é diferente. Bramante provavelmente não estava em um todo errado, pois de fato, Michelangelo tinha mais segurança para trabalhar no mármore como escultor do que em afresco $^{29}$ e a pintura foi a arte que nunca levou como sua principal habilidade. Além disto, nenhum outro artista tinha pintado um teto de tamanha proporção.

O projeto que Júlio II sugeriu a Michelangelo era o de pintar doze profetas ao longo das lunetas da capela, mas o artista, contrariando tudo isto e principalmente a Bramante, resolveu mudar toda esta concepção e preencher todo o teto com figuras humanas de proporções perfeitas. Com a mudança do projeto, Michelangelo sabia que ficaria cada vez mais distante de seu real objetivo, que era o túmulo de Júlio II, mas também sabia que o teto era um grande empreendimento e que engrandeceria ainda mais o seu nome, tanto que ao invés de trabalhar com uma grande equipe, ele decidiu trabalhar praticamente sozinho em cada detalhe do teto da capela. Por um lado para minimizar seus gastos e por outro, para não dividir sua glória, Michelangelo a vida inteira teve problemas em trabalhar com outras pessoas.

O teto foi a oportunidade de Michelangelo utilizar muitas de suas ideias para o túmulo de Júlio II em forma de pintura. Ao todo, foram quatro anos (1408-1412) de árduo trabalho, agonia e no final, êxtase.

Michelangelo tinha uma personalidade muito forte para se submeter à pintura, que julgava ser uma arte inferior à escultura, mas graças ao seu turbulento relacionamento com Júlio II juntamente com a insistência e pulso firme do Papa, Michelangelo se consagrou como um dos maiores artista da humanidade após o feito da capela Sistina.

Júlio II morreu poucos meses após a conclusão do teto da Sistina, e apesar de ter sido um papa terrível em algumas ações, deixou como legado uma Igreja de pé, com

\footnotetext{
${ }^{29}$ Técnica de pintura sobre gesso ou massa fresca.
} 
recursos, e muito diferente da decadência em que outros pontífices a deixaram. Além disto, Júlio II deixou como legado a genialidade assombrosa de Michelangelo ao obrigalo mostrar suas qualidades antes omitidas.

\section{OS PAPAS MEDICI.}

\subsection{Leão X, O Papa Mundano.}

17 de Março de 1513, Giovanni de’ Medici, recebe a maioria dos votos e é eleito pontífice sob o nome de Leão X (1513-1521). Desde criança, Giovanni foi preparado para o clero. De acordo com Scotti (2006,p.136), tornou-se padre aos oito anos, abade do mosteiro beneditino de Monte Cassino aos onze e cardeal com apenas treze anos.

Filho de Lourenço o Magnífico, Leão X era o oposto de Júlio II. Divertido, educado e muito espirituoso, fez de Roma novamente o centro cultural do mundo de acordo com McBrien (2009, P.279).

Torna-se necessário contextualizar o estado de espírito da Igreja renascentista que ao contrário da Igreja medieval não pensava nos pecados e na remissão destes como forma de controle e política, mas sim no sentido de o homem ser o centro, e por este ser a imagem e semelhança de Deus, o paraíso era na terra e os homens que eram incumbidos da missão deixada pro Jesus, abusavam dos luxos mundanos. A beleza estava acima da bondade.

Nos primeiros anos do pontificado de Leão $\mathrm{X}$, o papa trouxe de volta alguns artistas florentinos que de acordo com Scotti (2006, p.141), Bramante tinha conseguido marginalizar durante o pontificado de Júlio II, como o exemplo, o arquiteto Giuliano da Sangallo que retornou após a eleição de Leão X para projetar um novo palácio Medici na Piazza Navona. Além disto, Leão X tinha muito apreço por um jovem e carismático artista da cidade de Urbino, Rafael Sanzio (1483-1520), que já prestara anteriormente serviços a Júlio II.

Enquanto Michelangelo pintava o teto da Sistina, Rafael foi incumbido de pintar as stanze, ou salas papais do palácio do Vaticano. Em uma delas, fez um grande mural 
denominado A Escola de Atenas, onde o jovem artista pintou os mais influentes filósofos da Grécia antiga. Neste período, o artista rivalizou pela atenção e os recursos do papa com Michelangelo que era oito anos mais velho que Rafael. Tanto era o apreço de Leão X por Rafael que quando Bramante morreu em 1514, Rafael se tornou o capomaestro, ou seja, o arquiteto chefe da Basílica de São Pedro, mesmo sem ter nenhuma experiência.

Enquanto isso, nos primeiros anos do pontificado de Leão X, Michelangelo voltou a focar no projeto do túmulo de Júlio II, criando três de suas principais obras, sendo um Moisés $^{30}$ e dois escravos que ficaram incompletos e são denominados: Escravo rebelde e Escravo agonizante ${ }^{31}$.

Embora tivesse intimidade com Leão X por terem convivido na casa dos Medici, Michelangelo, já em seus quarenta anos de vida em 1515, ainda não havia sido procurado pelo papa para nenhum trabalho, e desta forma o artista resolveu voltar para Florença para continuar focando no túmulo de Júlio II, mas com esperança de ser chamado em breve pelo atual pontífice para trabalhar.

O que se sabe, é que de acordo com Gayford (2015, p.296), Michelangelo recebeu uma pequena encomenda de Leão X, provavelmente ainda em 1515. Esta encomenda se trata do projeto para uma fachada de uma pequena capela privativa que estava sendo construída no Castel Sant'Angelo ${ }^{32}$, em Roma.

Torna-se um ponto curioso entender o motivo de Michelangelo aceitar encomendas pequenas mediante a sua genialidade e seu ego enquanto Rafael cuidava da principal obra de Roma. Neste momento Michelangelo certamente estava aflito, pois sabia que teria que terminar a tumba de Júlio II, e inclusive estava sendo pressionado pelo sobrinho do pontífice, Francesco Maria della Rovere (1490-1538), o Duque de Urbino.

\footnotetext{
${ }^{30}$ O Moisés é a única estatua do projeto original do túmulo de Júlio II que ficou pronta e que está no projeto final do túmulo, na igreja de San Pietro in Vincoli, Roma.

${ }^{31}$ Estas estátuas estão no museu do Louvre, França.

${ }^{32}$ Capela de São Cosme e Damião.
} 
Uma grande reviravolta neste caso e que pode ter ajudado Michelangelo, foi que o Papa Leão X tomou a cidade de Urbino e excomungou Francesco, aliviando pelo menos naquele momento, a pressão que o artista estava sentindo. Gayford (2015, p.308) relata que foi provavelmente neste período que o papa Leão $\mathrm{X}$ encomendou para $\mathrm{o}$ artista uma grande fachada para a igreja da família Medici em Florença, a igreja de San Lorenzo.

Michelangelo teria pela frente uma empreitada nova, pois se tratava de um projeto arquitetônico cujo artista nunca havia trabalhado e desta vez ele necessitaria trabalhar com outras pessoas no mesmo projeto, algo que era muito complicado tendo em vista a dificuldade do artista em dividir os méritos. O papa e Michelangelo discutiram bastante sobre os detalhes do projeto desta obra que para o artista, era a chance de agradecer tudo que os Medici por ele fizeram e ao mesmo tempo de realizar outro grande feito, como foi o Davi em sua cidade, Florença. Quando assumiu o pontificado, Leão X era o atual governante de Florença e mesmo com o papado, não deixou seus interesses políticos e pessoais em prol da Igreja.

Todas essas coisas custaram um alto preço aos cofres do Vaticano. Festas sem fim, excessos de todos os tipos, a obra da São Pedro iniciada por Júlio II e as guerras políticas, ocasionaram em um esvaziamento dos recursos da Igreja. Desta forma, de acordo com McBrien (2009, P.280), a fim de sanar as altas dívidas resultantes de seu pontificado, Leão X decide vender cargos eclesiásticos, inclusive chapéus cardinalícios, além de renovar a venda de indulgências que foram autorizadas no pontificado anterior, de Júlio II.

Motivado por todas essas questões e por ter visto a situação da Igreja em Roma alguns anos antes, foi que um monge agostiniano da Saxônia ${ }^{33}$ resolveu em 1517, fixar na porta da igreja do Castelo de Wittenberg, noventa e cinco teses contra a Igreja Católica e, sobretudo, sobre a forma que a Igreja usava e adquiria recursos.

Martinho Lutero (1483-1546) cita dentre suas noventa e cinco teses as seguintes:

"No50: Deve-se ensinar aos cristãos que, se o papa soubesse das exações dos pregadores de indulgências, preferiria reduzir a cinzas a Basílica de São Pedro a edifica-la

\footnotetext{
${ }^{33}$ Faz parte da Alemanha.
} 
com a pele, a carne e os ossos de suas ovelhas. $\mathrm{N}^{\circ} 82$ : Por que o papa não libera todos do purgatório em nome do amor (que é santíssimo) e da extrema necessidade das almas? Essa seria moralmente a melhor de todas as causas. No entanto, ele redime inúmeras almas pelo dinheiro sumamente perecível com que construir a Basílica de São Pedro, que é uma causa insignificante" SCOTTI (2006, p. 169 apud Lutero).

Michelangelo também escrevia em seus poemas secretos sobre o que pensava da atual Igreja. Em um desses poemas, pouco antes da morte de Júlio II, ele diz que Cristo já não tem lugar em Roma, já que "seu corpo está sendo vendido e todos os caminhos que levam à virtude estão fechados". Michelangelo neste ponto parece um zeloso reformador, sentindo a necessidade de mudanças na Igreja, por um lado por que via como as coisas aconteciam de dentro da Igreja e por outro, por que isso provavelmente prejudicava seus interesses artísticos.

Não bastassem os problemas que a Igreja enfrentava em seu pontificado, Leão X passaria por um momento delicado em que inesperadamente em 1519, seu sobrinho, Lorenzo II de Medici (1492-1519) esperança futura da dinastia, faleceu precocemente aos vinte e seis anos de idade. Este foi um duro golpe e associado às dívidas da Igreja anteriormente citadas, o projeto da fachada se estagnou e acabou não sendo concluído.

Outro duro golpe sofrido por Leão $X$ foi a também inesperada morte de seu artista predileto, Rafael Sanzio que morreu aos trinta e sete anos em 1520. A morte de Rafael levou o papa a repensar seus projetos em andamento, e em uma dessas ocasiões ele disse de acordo com Gayford (2015, p.336), o que realmente pensava sobre Michelangelo e o motivo de Rafael e não Michelangelo ser o mais próximo na corte papal.

Leão X de acordo com o relato de um amigo de Michelangelo, o também artista Sebastiano del Piombo (1485-1547) tinha grande apreço por Michelangelo, e quando falava do artista era como se falasse de um irmão, mas que a restrição ficava por conta da forte personalidade do artista que chegava a amedrontar o próprio pontífice, o termo usado foi a terribilità de Michelangelo. O que segue é que após repensar seus projetos o papa resolveu criar um túmulo em homenagem à família Medici, e elegeu Michelangelo como o responsável pela obra. Esta só foi concluída em 1533, sob a tutela de outro papa Medici. 


\subsection{Adriano VI, Um Ponto na História.}

Em 1521, depois de um período febril, o papa Leão X morreu. Deixou de legado uma Igreja endividada, os cofres vazios e uma grande confusão política onde, de acordo com McBrien (2009, P.280), a Europa estava prestes a explodir em um conflito religioso. Motivados por isto e sabendo que a Igreja necessitava "desintoxicar", os cardeais que se reuniram no conclave papal no final de 1521 , elegeram um papa muito diferente do guerreiro Júlio II ou do amante da vida mundana, Leão X.

Adriaan Floriszoon Boeyens, de Utrecht, Holanda, foi eleito em 1522 conservando seu nome de batismo, tornando-se Adriano VI (1522-1523).

Seu projeto de papado, de acordo com McBrien (2009, P.284), se baseava na ideia de conter a Reforma protestante por meio de uma reforma na administração geral da Igreja e da união do Ocidente cristão com os turcos, que representavam uma grande ameaça por suas invasões violentas. De acordo com Gayford (2015, p.343), quando foi eleito, Adriano VI atuava como vice-rei na Espanha, desta forma, até de fato chegar a Roma para exercer o pontificado, foram cerca de oito meses.

Logo que souberam o resultado da eleição papal, os cidadãos romanos não se mostraram muito contentes pelo fato do papa não ser italiano e pior ainda, pelo fato de ser um "bárbaro", como costumavam associar com preconceito os povos germânicos e holandeses.

Fato é que Adriano VI carregava insensibilidade e muita frieza na bagagem, sendo o primeiro papa em quase vinte anos que não quis saber dos serviços de Michelangelo, mas todavia, considerava um grande absurdo conforme relata Gayford (2015, pp. 349,350) que o túmulo de Júlio II, após dez anos de sua morte ainda não estar concluído, e portanto redigiu um documento onde expressava que Michelangelo deveria concluir a sepultura ou devolver todo o dinheiro que lhe foi pago.

Michelangelo, por sua vez estava em um impasse, pois por causa das obras encomendadas pelo papa Leão X em homenagem aos Medici, deixou o túmulo de Júlio II cada vez mais em segundo plano. 
Por causa de sua seriedade, amargura e até mesmo honestidade, que Adriano VI não conseguia levar adiante seus projetos de pontificado. Roma e toda a profanação presente na Igreja, não estavam preparadas para uma mudança tão brusca, tanto que em pouco tempo já deviam sentir falta do papa Leão X e seus liberalismos. O papado de Adriano VI IV teve seu fim em 1523, não deixando praticamente nada de legado em seu breve pontificado.

\subsection{Clemente VII, Decisões Precipitadas.}

Após o rápido pontificado de Adriano VI, os cardeais se reuniram mais uma vez para eleger o novo líder da Igreja E dessa forma, um entre eles, foi eleito sobre o nome de Clemente VII (1523-1534).

O nome de batismo de Clemente VII era Giulio de' Medici, filho ilegítimo de Giuliano de' Medici (irmão de Lourenço o Magnifico), portanto Clemente VII era primo de Leão X. Clemente VII foi anteriormente beneficiado, pois seu primo Leão X o retirou da proibição canônica de ordenar filhos ilegítimos, ou seja, nascidos fora do casamento.

Clemente VII de acordo com Vasari (2011, p.729), solicitou logo os serviços de Michelangelo que a pedido do papa, retornou à Florença para realizar o projeto de uma abóbada $^{34}$ para a Sacristia Nova da Basílica de San Lorenzo e dentro desta abóbada, Michelangelo planejou fazer quatro sepulturas como ornamentação na parede para os Medici falecidos, sendo estes: Lourenço de Medici, o Magnífico; Giuliano de Medici; Giuliano II de Medici e Lorenzo II de Medici.

Michelangelo terminou de fato apenas as duas ultimas sepulturas citadas acima, mas o que é bastante relevante, é que Michelangelo de acordo com Vasari (2011, p. 729) começou a se distanciar do estilo clássico e de suas proporções perfeitas, focando mais no estilo emocional do que racional, e desta forma, incentivou diversos artistas a praticarem novas fantasias na $\operatorname{arte}^{35}$.

\footnotetext{
${ }^{34}$ Estrutura arquitetônica de cobertura curvada.

${ }^{35}$ Vasari se refere a Michelangelo talvez como o artista que foi o precursor do estilo Maneirista.
} 
O papa tinha Michelangelo como seu artista favorito e de acordo com Gayford (2015, p. 362), se preocupava em como Michelangelo tinha dificuldades em trabalhar com outros artistas por conta de seu temperamento. Mesmo com as crises na Igreja, e um cenário político tumultuado, o papa separava um tempo considerável para atender os caprichos de Michelangelo, pois sabia que os resultados seriam gratificantes.

Clemente VII e Michelangelo também se correspondiam diretamente por cartas, o que não era muito comum entre os pontífices e artistas, e o tratamento destas correspondências, de acordo com Gayford (2015, p.364) era algo mais íntimo, em primeira pessoa.

Scotti (2006, p.189) relata que tal era a intimidade entre o artista e o pontífice, que Clemente VII chegou a dizer as seguintes palavras: "Quando Buonarroti vem me visitar, sempre sento e lhe ofereço uma cadeira, pois intuo que ele se sentará sem pedir licença".

Um ponto relevante sobre a personalidade de Clemente VII é que embora fosse sereno e paciente, o seu jeito dissimulado e a falta de pulso firme necessária para o mais alto cargo da Igreja, geraram problemas sem precedentes. Clemente VII teve um pontificado marcado por péssimas escolhas, tanto que em uma destas, ele ocasionou um novo saque à cidade de Roma, em 1527.

Por causa de suas lealdades indecisas primeiramente apoiava o rei Francisco I (1494-1547) da França, enfurecendo o imperador Carlos V (1526-1539) da Espanha, porém Francisco I foi derrotado e Clemente VII foi buscar apoio de Carlos V, mas posteriormente traiu o imperador se unindo com exércitos italianos contra Carlos V.

De acordo com Gayford (2015, p. 388), para muitos, o terrível saque de Roma foi como a realização das profecias de Girolamo Savonarola (1452-1498), ${ }^{36}$ de que a corrupção de Roma estava sendo punida assim como a citação bíblica de Sodoma e Gomorra.

\footnotetext{
${ }^{36}$ Foi um pregador que dirigia duras críticas a corrupção de Roma e ao paganismo renascentista. Queimou com frequência obras de arte em suas denominadas: "fogueira das vaidades" e chegou a ser inclusive o líder de Florença por um período até ser morto em 1498 a mando do papa Alexandre VI.
} 
Seguido do saque de Roma viria ainda uma epidemia de peste e embora Florença, onde Michelangelo ficou durante o saque fizesse parte das zonas de surto, o artista permaneceu na cidade trabalhando.

Clemente VII por sua vez, retornou a Roma após todos os acontecidos, com uma grande barba que não fazia desde o exílio, em luto por Roma, assim como faziam os antigos imperadores.

Voltou humilhado, abatido, mas ainda com uma "carta na manga", sendo esta a decisão de chegar a um acordo com Carlos V que se tornou o imperador do Sacro Império Romano e ganhou territórios italianos. Clemente VII só entendeu, lamentavelmente para Roma, que desde o início deveria ter se aliado somente ao poderoso imperador.

Após as questões políticas se restabelecerem, o papa Clemente VII queria ajudar seu artista favorito a se livrar de um grande fardo, o túmulo de Júlio II, que mesmo depois de Adriano VI instituir que este deveria ser concluído não havia sido feito. Clemente VII queria mediar um novo acordo entre o artista e os familiares de Júlio II para que o artista terminasse de vez o serviço a fim de resolver questões políticas com a família della Rovere e ter Michelangelo exclusivamente para as obras em San Lorenzo.

Algum tempo se passou entre Roma e Florença, Michelangelo ainda não tinha terminado o túmulo de Júlio II, mas ainda estava concentrado na igreja de San Lorenzo e no projeto da Biblioteca dos Médici, quando de acordo com Vasari (2011, p. 733), após se encontrar com Michelangelo em Roma, o papa resolveu aliviar o trabalho do artista dividindo a tarefa com outros escultores e acelerando desta forma a conclusão das obras em Florença.

Vasari relata que o papa não deixou Michelangelo voltar a Florença imediatamente após este encontro, pois queria o artista ao seu lado para produzir um grande mural na Capela Sistina, onde Michelangelo já tinha pintado o teto. Um ano se passou e antes de Michelangelo começar este grande mural, o papa Clemente VII morreu em 1534. 


\section{UMA RESPOSTA A REFORMA PROTESTANTE.}

Após, praticamente, a sucessão de papas Medici, e o trágico legado deixado de herança por estes, a Igreja necessitava despertar. A Reforma veio como uma grande explosão para que isto pudesse de fato acontecer em mil e quinhentos anos de história da Igreja. A Reforma Protestante foi evidentemente a maior crise que a Igreja enfrentou e como não foi devidamente levada a sério pelos seus últimos papas, coube a um cidadão legitimamente romano e profundo conhecedor da instituição, ir adiante e tentar remendar as feridas, levando em consideração os pontos que necessitavam de mudanças.

\subsection{Paulo III, O Papa da Contra-Reforma.}

Paulo III (1534-1549), nascido Alessandro Farnese foi eleito por unanimidade no conclave de 1534. Homem de conhecimento perspicaz sobre a Igreja era conhecido antes do papado como cardeal "das saias", isto por que era irmão de Giulia Farnese (1474-1524), amante do papa Alexandre VI (1492-1503), que por sua vez nomeou Alessandro ao cardinalato.

De acordo com Scotti (2006, p. 92) Paulo III era o Pontifex Maximus, ou seja, o "supremo construtor de pontes", pois foi o homem capaz de transpor a linha divisória entre o renascimento romano e a Contra-Reforma.

Paulo III foi assertivo em nomear cardeais sérios como Giovanni Pietro Carafa (1476-1559), que posteriormente foi eleito ao papado, o inglês e amigo de Michelangelo, Reginald Pole (1500-1558) que foi um grande reformador, S. John Fisher (1469-1535) que foi um grande defensor da Igreja na Inglaterra, Giovanni Morone (1509-1580) também importante reformador, além de outro futuro papa, Marcello Cervini (1501-1555), e Gasparo Contarini (1483-1535) que foi um valioso colaborador de Paulo III para a reforma da Igreja.

Em relação a Michelangelo, de acordo com Gayford (2015, p. 445) a morte de Clemente VII tirou de Michelangelo um protetor dedicado e um admirador fiel, mas que de certa forma aliviou o artista por não necessitar levar a diante os projetos da San Lorenzo e menos ainda o do grande mural na Sistina, considerando que o artista agora já 
se considerava idoso e fraco na casa de seus 60 anos de idade. Mas, assim que se tornou papa, Paulo III chamou Michelangelo para trabalhar em seu nome e continuar a empreitada sugerida por Clemente VII, o tema era o Juízo Final que estamparia o altar da capela Sistina.

Michelangelo, de acordo com Gayford (2015, p. 446) relutou em aceitar esta encomenda e explicou ao papa Paulo III, que deveria enfim terminar o túmulo de Júlio II que se arrastava por trinta anos e ainda não havia sido concluído conforme o contrato.

O Papa por sua vez, tentou persuadir o artista alegando que passou uma vida aguardando o momento de poder desfrutar do talento de Michelangelo e agora que finalmente poderia, não aceitaria ser frustrado e se necessário, rasgaria o contrato entre Michelangelo e a família de Júlio II referente ao túmulo.

Michelangelo que já tinha convivido com outros papas, esperava que Paulo III não demoraria a morrer, uma vez que o papa foi eleito em idade avançada (sessenta e sete anos) e desta forma, foi postergando a pintura até que as circunstâncias mudassem conforme relata Gayford (2015, p. 447 apud Vasari). Fato é que Paulo III teve o maior pontificado do século XVI, sendo papa por 15 anos.

Desta forma, cerca de seis meses após a eleição de Paulo III, Michelangelo começou o projeto para a pintura do mural, que assim como foi no teto da Capela Sistina anos antes, essa era uma outra tarefa hercúlea, pois a parede conta com uma área de catorze por treze metros, correspondendo a cento e oitenta e dois metros quadrados.

Paulo III foi estreitando sua relação com Michelangelo a ponto que, de acordo com Gayford (2015, p.449), ainda no primeiro ano de pontificado, Paulo III emitiu duas bulas papais ${ }^{37}$ que tornavam Michelangelo o "arquiteto, escultor e pintor supremo da Igreja, e membro com todos os favores, prerrogativas, honras e preferências que os outros membros do palácio apostólico desfrutavam”. O papa ainda deu a Michelangelo uma renda vitalícia de mil e duzentos scudi ${ }^{38}$ anuais. Paulo III dizia ao artista que esta quantia vitalícia é um merecimento porque o via trabalhando perpetuamente para o papado.

\footnotetext{
${ }^{37}$ Alvará passado pelo papa com força de lei eclesiástica.

${ }^{38}$ Moedas de prata usadas nas penínsulas italianas.
} 
Gayford (2015, p. 450) relata que durante uma das visitas do papa ao artista para falarem da pintura do Juizo Final e de outros projetos como o a tumba de Júlio II ainda incompleta, um dos cardeais que acompanharam Paulo III, ao ver a estátua do Moisés insinuou que de tão bela já bastava como "homenagem no sepulcro de Júlio II". E desta forma o papa concordando com o cardeal resolveu por meio de um motu próprio ${ }^{39}$, liberar Michelangelo, seu "amado filho", aquele "singular e único pintor e escultor" de terminar a sepultura de Júlio II de acordo com o contrato em vigor, procrastinando mais uma vez o antigo projeto e desta forma, oficialmente em 1536, Michelangelo começou a pintar o Juizo Final.

Esta empreitada consumiu mais anos da vida de Michelangelo que começou com sessenta e dois e terminou com sessenta e sete, do que o artista levou no teto da mesma capela. Foi nesta pintura que Michelangelo se retratou apenas como a pele na mão de São Bartolomeu, representando-se como algo velho, no final da vida, um reflexo de como o artista de fato se sentia, além disto, retratou de forma furiosa um homem que questionou o fato de tantas imagens nuas serem pintadas em um local santo.

Este, sendo Biagio da Cesena (1463-1544) mestre de cerimonias papal, ao criticar a pintura, foi posteriormente pintado como o demônio Minos que possui orelhas de burro e uma grande serpente enrolada em suas pernas com presas cravadas em seu pênis.

Entretanto, não foi apenas Biagio da Cesena que reagiu com críticas a obra. De acordo com Gayford (2015, p.467), os teatinos, uma ordem austera da Igreja, dedicada a por limites nos gostos mundanos do clero e dos leigos, considerou a obra indecente por conter tantos nus.

Por outro lado, houve muitos defensores, e principalmente no público leigo, Michelangelo alcançou o desejado pelo papa Paulo III, pois o Juízo Final mostrou a resposta da Igreja com muita força perante o protestantismo que tinha cada vez mais adeptos. Foi um recado de que embora ferida, a Igreja ainda era a força soberana, e quem ousasse ir contra, poderia ser punido terrivelmente no dia do julgamento final.

\footnotetext{
${ }^{39}$ Traduzido como "próprias mãos” é um documento normativo escrito pelo próprio pontífice.
} 
Bastou Michelangelo concluir os afrescos do Juízo Final em 1541, para o papa encomendar outro serviço a Michelangelo, dessa vez em uma nova capela que Paulo III tinha mandado construir, denominada Capela Paulina. Foi também neste período, de acordo com Gayford (2015, p.472), que Michelangelo finalmente começou a resolver o impasse sobre o túmulo de Júlio II.

Como Michelangelo já estava em idade avançada (sessenta e sete anos), houve um novo acordo, muito pelo medo que tinham de o artista morrer antes de terminar o túmulo, e desta forma ficou acordado que o projeto final da sepultura de Júlio II seria muito menor e bem diferente dos projetos anteriores ao longo de quarenta anos de modificações e postergações. Além disto, Michelangelo por fim concordou que o túmulo seria terminado com a ajuda de outro artista, Rafaello da Montelupo (15041566), sendo que o Moisés de Michelangelo seria a peça chave da sepultura junto de duas outras esculturas, a Vida Contemplativa e a Vida Ativa, também projetadas pelo artista.

Finalmente em 1545, o túmulo de Júlio II estava entregue em seu novo local de instalação, a igreja de San Pietro in Vincoli em Roma, até porque a Basílica de São Pedro que seria o local original estava bem longe de sua conclusão. Também foram finalizados os primeiros afrescos da Capela Paulina, onde Michelangelo retratou a Conversão de Saulo.

Ao analisar estes anos iniciais em que Michelangelo realizou as encomendas de Paulo III $^{40}$, chega a impressionar o fato de como o artista já idoso, e por vezes seriamente enfermo ${ }^{41}$, trabalhou ainda com tanto vigor em empreitadas tão grandes.

O papa Paulo III ainda iria incumbir Michelangelo de mais uma grande empreitada, para provar que Michelangelo é um artista completo em toda a gênese da palavra e em todos os desafios possíveis a um artista daquele período.

\footnotetext{
40 Juízo Final e Capela Paulina.

41 Michelangelo teve duas graves crises febris relatadas entre 1542-1546, período em que trabalhava simultaneamente na Capela Paulina e no túmulo de Júlio II.
} 


\subsection{Michelangelo, o Arquiteto Chefe Da São Pedro.}

É sabido que Michelangelo se denominava acima de todas as suas qualificações como escultor. Pelo menos até certo ponto de sua vida ${ }^{42}$, assinava como Michelangelo, escultor e desta forma, se pudesse, jamais escolheria a pintura, por exemplo, como primeira opção de trabalho.

Mas como sempre ocorrera na vida de Michelangelo, mais uma vez ele seria imposto de uma missão que provaria seus talentos.

Conforme relata Scotti (2006, p.211), após a morte do capomaestro da Basílica de São Pedro, Antonio da Sangallo, o jovem (1484-1546), que era conhecido de Michelangelo por ser sobrinho dos também arquitetos e florentinos, Antonio da Sangallo, o velho (1455-1534) e Giuliano da Sangallo, já citado ao longo deste trabalho, houve a necessidade de se eleger um novo arquiteto chefe para continuar com as obras da principal Igreja da cristandade.

Nomes de possíveis arquitetos para o empreendimento colossal chegaram até Paulo III, que resolveu ele mesmo eleger um artista de sua preferência, e claro, foi a Michelangelo que o papa incumbiu de ser o arquiteto chefe das construções começadas por Júlio II e Bramante, logo quando Michelangelo começou a trabalhar em Roma em 1505 .

Michelangelo, assim como relutou na época de Júlio II para pintar o teto da Sistina, relutou também em assumir o controle da obra da São Pedro. O artista que não gostava de trabalhar em conjunto de outras pessoas alegava que não confiava na Fabbrica $^{43}$ de São Pedro que só queria enriquecer, e alegava também que nunca tinha controlado tantas pessoas ao mesmo tempo.

De acordo com Scotti (2006, pp.213-214), "Paulo III pressionou. Michelangelo deu desculpas. Paulo III persistiu. Michelangelo recusou. Paulo III adulou, institui, lisonjeou e até mesmo ordenou".

\footnotetext{
${ }^{42}$ Nos anos finais de sua vida, Michelangelo preferia ter o tratamento de um senhor de classe nobre, e não apenas como alguém que fez maravilhas na arte.

43 A Fabbrica é o órgão administrativo responsável por cuidar das despesas e demais controles das construções da Basílica de São Pedro, assim como o exemplo da Opera del Duomo que era a responsável pelas obras da Basílica de Santa Maria del Fiori em Florença nos tempos de Donatello (1386-1466) e Brunelleschi (1377-1446).
} 
Por fim, em 1547, com "infinito pesar" Michelangelo concordou em se tornar o principal arquiteto da Basílica de São Pedro. Para tal, o artista, de acordo com Scotti (2006, p. 214), fez exigências ao papa em que teria autoridade absoluta, completa e total e que isto só poderia ser mudado pelo próprio papa.

Paulo III atendeu a exigência e em 1549 escreveu um motu proprio dando autoridade completa a Michelangelo referente às obras da Basílica de São Pedro, ou seja, de agora em diante, ninguém com exceção do próprio papa, poderia questionar o que Michelangelo fizesse na construção de São Pedro.

Outro ponto excepcional é que Michelangelo se absteve de remuneração referente ao cargo, pois considerava ser uma penitência imposta pelo próprio Deus e desta forma, faria tudo pela glória do Senhor e não pelos homens.

Os funcionários da Fabbrica acreditaram que o trabalho seguiria conforme o projeto de Sangallo que vinha em ritmo acelerado visto que anteriormente as obras da São Pedro ficaram praticamente estagnadas durante o pontificado dos Medici, mas a surpresa é que mesmo com a idade, o temperamento de Michelangelo em relação ao trabalho e a perfeição em nada mudou, e de acordo com Scotti (2006, p.215), o artista rejeitou todos os projetos de Sangallo.

Michelangelo considerou o projeto muito sombrio, com poucas janelas e, além disto, notou que o projeto era grande demais, ornamentado em excesso (fugindo do clássico), além de ser um projeto extremamente caro mediante a crise da Igreja, e chegou ainda a de forma indireta elogiar seu antigo rival Bramante quando Michelangelo diz, de acordo com Scotti (2006, p.215), que "Sangallo profanou o projeto de Bramante, se afastando da iluminação conseguida pelo artista anterior" e ainda que "Quem distancia das disposições de Bramante, distancia-se da verdade".

Michelangelo resolveu repensar toda a estrutura da fachada e da cúpula, e embora tenha feito elogios ao projeto original de Bramante, fez seu projeto de forma bem diferente.

É de se notar que mesmo assumindo o posto de arquiteto chefe e repensando todo o projeto da basílica, Michelangelo ainda estava concluindo seus últimos afrescos na Capela Paulina, onde já no fim da vida de Paulo III, Michelangelo pintou a crucificação de São Pedro. 
De acordo com Gayford (2015, p.505), menos de um mês depois de Paulo III fazer sua última inspeção na crucificação de São Pedro, aos oitenta e dois anos, Paulo III morreu após um longo pontificado e fervilhado de renovações, obras e ideias.

Se Júlio II deu o pontapé na arte de Michelangelo, Paulo III foi quem a renovou, pois acreditou, deu forças e confiou em um artista já considerado por muitos em seus "últimos momentos de vida". Servindo a Paulo III, Michelangelo realizou mais obras já em idade avançada do que fizera em grande parte de sua vida adulta após a morte de Júlio II e durante a sucessão de outros papas.

\section{5. ÚLTIMOS ANOS DE MICHELANGELO, ARQUITETO SUPREMO.}

Paulo III foi o último papa com o qual Michelangelo testou de fato seus limites e foi incumbido de árduas tarefas. Paulo III irrigou novamente o rico terreno da Igreja, livrando-o das pragas inseridas principalmente pelos Medici e deixando-o fértil para os próximos papas que o sucederam. Michelangelo ainda trabalhou por quinze anos com quatro papas distintos até sua morte.

Aqui se observa, que os últimos pontífices a quem Michelangelo serviu, mantiveram o artista focado especificamente como arquiteto da Basílica de São Pedro. Tendo Michelangelo cada vez mais autoridade sobre o projeto da principal igreja da cristandade, a confiança do clero no artista se afirmava.

Júlio III (1550-1555), Marcelo II (1555-1555), Paulo IV (1555-1559), e Pio IV (1559-1565) foram os últimos patronos da vida do artista, e embora cada um deles tivesse uma proposta distinta de pontificado e personalidades ainda mais distintas, ambos concordaram que as obras da basílica deveriam continuar sob a coordenação do artista.

Mesmo com a reclamação de arquitetos mais jovens que, de acordo com Scotti (2006, p.221), constantemente alegavam que Michelangelo não estava mais em condições físicas e mentais, e que isto prejudicaria o projeto e o andamento das obras, os papas não cederam à pressão e até mesmo ameaçaram repreender qualquer um que ousasse reformar ou alterar qualquer minúcia feita por Michelangelo, como foi o caso 
de Júlio III, que chamava formalmente Michelangelo como "Vossa Senhoria" conforme relata Scotti (2006, p.220).

De acordo com Gayford (2005, pp.513-514 apud Condivi), tanta era a admiração do papa Júlio III por Michelangelo que este não só declarou que daria anos de sua própria vida e seu sangue se isso fosse possível para fazer Michelangelo viver mais, como também disse que caso o artista morresse durante o seu pontificado, ele mandaria que o embalsamassem e manteria o corpo deste artista fabuloso próximo de si.

Estes relatos são reflexos da autoridade e do respeito que Michelangelo alcançou através dos trabalhos anteriores, particularmente com o papa Paulo III, provou que era capaz, e mesmo no fim da vida continuou sempre preocupado em excesso.

\footnotetext{
“Aos 86 anos, Michelangelo continuava engajado na arte - obstinado, intransigente, inClemente VII, sem poupar a si mesmo nem aos outros. Aos poucos, a nova igreja começou a despontar segundo os seus termos, de acordo com sua visão”. SCOTTI (2006, p. 221).
}

Michelangelo se preocupou em deixar a obra da basílica em certo ponto, que não teria mais jeito de ser alterada por nenhum arquiteto posterior, mas por algum descuido de acordo com Gayford (2015, p.529), Michelangelo não acompanhou de perto uma parte da construção da basílica que foi erigida de forma errada, tendo de ser posteriormente demolida, causando um duro golpe no artista e servindo de munição aos que desejavam assumir o posto de Michelangelo.

Algo que deve ser levado em consideração, é que mesmo sem cobrar nenhuma remuneração pela tarefa de ser o arquiteto da São Pedro, e por ter plena confiança dos pontífices, ainda assim Michelangelo teve sua renda vitalícia cortada pelo papa posterior a Júlio III, Paulo IV.

Paulo IV foi extremo conservador, puritano, censurou livros, marginalizou os Judeus que viviam em Roma, e constantemente criticava os nus pintados de Michelangelo. Em uma dessas críticas, de acordo com Gayford (2015, p.528), mandou Michelangelo "ajeitar" os afrescos do Júizo Final. Michelangelo irascível, indiretamente respondeu que: "isto é uma questão de detalhes que facilmente é resolvido, mas que o papa deveria se preocupar em consertar o mundo, pois arrumar imagens é muito simples". 
É de se notar que mesmo com a idade cada vez mais avançada, e as incumbências da obra da São Pedro, Michelangelo não aposentou o cinzel.

$\mathrm{O}$ artista em suas horas vagas utilizava as forças que lhe restavam para martelar o seu material preferido, o mármore, onde de acordo com Gayford (2015, p.510), para tais, Michelangelo utilizava um chapéu com uma vela na ponta para esculpir na escuridão da noite em seu ateliê.

Já no fim da vida, Michelangelo recebeu um auxiliar de grande valor, sendo este, Tibério Calcagni (1532-1565) que almejava ser escultor e teve Michelangelo como mestre.

De acordo com Gayford (2015, p.531), Tibério auxiliou Michelangelo a concluir algumas esculturas que o mestre a muito tinha deixado de lado como um Bruto $^{44}$ e uma Pietá $^{45}$ que Michelangelo pretendia doar a uma igreja. Esta Pietá foi destruída quase por completo por Michelangelo que ao decorrer do trabalho encontrou imperfeições na obra e perdeu a paciência.

De acordo com Zöllner e Thoenes (2017, p. 651), ainda sobre o mesmo tema desta Pietá que foi quebrada, Michelangelo trabalhava em uma obra, que foi a sua última em vida, conhecida como Pietá Rondanini. Esta obra que hoje se encontra no Castello Sforzesco, em Milão retrata o Cristo morto nos braços da mãe.

Inacabada e muito martelada, a obra mostra a força com que Michelangelo tentava expelir da pedra, formas perfeitas, sobretudo, como uma vida própria impressionante, pois se assemelha algo que está em evolução.

Michelangelo encontrou também em seus últimos momentos de vida, um papa disposto a usar os talentos do idoso artista. Pio IV, foi um sonhador e amante das artes, este voltou a pagar o salário vitalício concedido por Paulo III a Michelangelo e planejou junto com o artista, de acordo com Gayford (2015, p.537), a chamada Porta Pia, que era uma porta festiva e fantasista na parte leste das muralhas que cercavam Roma. Esta porta rompe com a arquitetura clássica, assim como todos os projetos arquitetônicos concebidos por Michelangelo para a Basílica de São Pedro, ou para a cidade de Roma.

\footnotetext{
${ }^{44}$ Esta escultura encontra-se no museu de Bargello, Florença.

${ }^{45}$ Pietá de Florença, se encontra no museu da Ópera del Duomo, Florença.
} 
Michelangelo possuía de fato uma mente fantasiosa em demasia, o que pode explicar o motivo de o artista destruir parcialmente suas últimas esculturas julgando-as imperfeitas. Além disto, a terribilità de Michelangelo também fez com que o artista queimasse diversos desenhos antes de partir do plano terreno.

Em 18 de fevereiro de 1564, aos oitenta e oito anos, e após prestar serviço a nove papas, influentes políticos, príncipes da Igreja e burgueses, a vida épica de Michelangelo chega ao seu capítulo final.

\begin{abstract}
"Porém, como disse no começo, o Céu o mandou aqui embaixo para servir de exemplo na vida, nos costumes e nas obras, para que aqueles que se miram nele, imitando-o, possam aproximar-se da eternidade por meio da fama, da natureza por meio das obras do estudo e do Céu por meio da virtude, do mesmo modo que ele sempre foi motivo de honra para a natureza e para o céu. E que ninguém se admire por ter eu descrito a vida de Micheleagnolo, estando ele ainda vivo, pois, como se espera que ele nunca morra, pareceu-me conveniente contribuir um pouco para a sua honra; e, embora ele venha a abandonar o corpo como todos os homens, suas obras imortais nunca encontrarão a morte: enquanto o mundo existir, a fama delas viverá sempre gloriosíssima nas palavras dos homens e na pluma dos escritores, malgrado a inveja e o despeito da morte.”VASARI (2011, p.739).
\end{abstract}

\title{
6. CONSIDERAÇÕES
}

Por grande parte da vida, e sempre pensando estar perto da morte, Michelangelo lamentou ser "pobre, velho e servo da vontade alheia", mas a grande ironia é que estas lamentações do artista, principalmente a de "servir a vontade alheia" fizeram de Michelangelo um artista de possibilidades infinitas.

Pode-se imaginar um Michelangelo sem os caprichos de Júlio II, ou sem a ousadia de Paulo III, mas certamente o artista não atingiria o mesmo patamar, pois foram as "vontades alheias" que desafiaram e elevaram Michelangelo a um nível artístico impressionante. Embora sempre "aprisionado" e cercado por diversos conflitos externos e internos, Michelangelo foi a personificação do artista moderno. 
Mestres como Leonardo (1452-1519) e Rafael, são outros exemplos de como os artistas do Renascimento italiano mudaram o significado do que é ser um artista e de conceber arte, mas nenhum deles se envolveu tão espiritualmente com a arte quanto Michelangelo Buonarroti.

Por conta deste envolvimento, sua devoção e perfeccionismo, Michelangelo por vezes ousou a ultrapassar a barreira do imaginário como fez na Capela Sistina por mais de uma vez, além de alcançar a vida eterna por meio de esculturas perfeitas como o Moisés.

Em pedra, Michelangelo fez correr sangue e deu alma a suas criações. Nenhuma obra da Roma ou da Grécia antiga, nem mesmo a escultura do Laocoonte encontrado nos tempos de Júlio II, supera em nada os feitos de Michelangelo que via na pedra muito além do que qualquer um viu, abrindo novas janelas na história da arte e possibilitando a artistas posteriores irem além da simples imitação da natureza.

Em relação aos pontífices, Michelangelo foi um "instrumento divino", pois através de seus talentos somados a carga emocional presente em suas obras, o artista conseguiu traduzir com um cinzel, os sentimentos de todo um período que foi fervilhante de novidades e inovações. Poucos artistas foram sensíveis a tal ponto de perceberem as mudanças e as possíveis soluções.

A própria Igreja Católica renascentista não seria a mesma sem a mão de Michelangelo para traduzir os escritos bíblicos em imagens magníficas, transformando em visível o que antes era invisível.

Ao final desta pesquisa, torna-se uma ingrata e atrevida tarefa tentar ao menos explicar como tantos sentimentos, preocupações, relações afetuosas, preceitos religiosos em constantes contradições, couberam em uma só pessoa. Se desmembrássemos a história de Michelangelo, utilizando vários personagens representando cada uma de suas características faria mais sentido.

Ao longo de seus oitenta e oito anos, e diversas obras de escultura, pintura, arquitetura e poesia, somadas em todos os fatores as fortes cargas emocionais, o resultado é Michelangelo, o artista dos papas, de Deus e da humanidade, um dos principais ícones do Renascimento e uma das maiores personalidades em toda a história da arte. 


\section{REFERÊNCIAS}

SCOTTI, Rita A. Basílica de São Pedro: esplendor e escândalo na construção da catedral do Vaticano. Rio de Janeiro. Nova Fronteira, 2006.

BERRIEL, Marina Jorge. Tradução comentada da obra "Vida de Michelangelo Buonarroti", escrita por Ascanio Condivi. 2008. 119 p. Dissertação (mestrado) Universidade Estadual de Campinas, Instituto de Filosofia e Ciencias Humanas, Campinas, SP. Disponível em: <http://www.repositorio.unicamp.br/handle/REPOSIP/279802>. Acesso em: 24 set. 2019.

BUONARROTI, Michelangelo. Cartas escolhidas. Campinas: Unicamp; São Paulo. Unifesp, 2009. Tradução de Maria Berbara.

GAYFORD, M. Michelangelo, uma vida épica. São Paulo. Cosac\&Naif, 2015.

ZÖLLNER, Frank; POEPPER, Thomas; THOENES, Christof. Miguel Ângelo - Obra Integral De Pintura, Escultura E Arquitetura, Taschen, 2017.

VASARI, Giorgio et al. Vidas dos artistas. São Paulo: Martins Fontes, 2011.

MCBRIEN, P. Richard. Os Papas. Os pontífices: de São Pedro a São João Paulo II. São Paulo. Edições Loyola, 2009. 